\title{
Selective Inhibition of NF-kB and Surfactant Therapy in Experimental Meconium-Induced Lung Injury
}

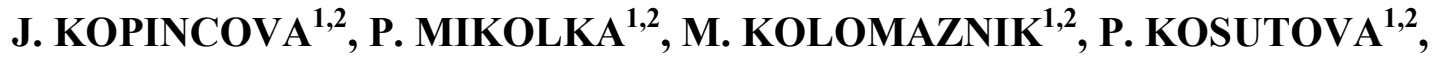 \\ A. CALKOVSKA ${ }^{1,2}$, D. MOKRA ${ }^{1,2}$
}

${ }^{1}$ Department of Physiology, Jessenius Faculty of Medicine in Martin, Comenius University in Bratislava, Martin, Slovakia, ${ }^{2}$ Biomedical Center Martin, Jessenius Faculty of Medicine in Martin, Comenius University in Bratislava, Martin, Slovakia

Received January 10, 2017

Accepted February 26, 2017

\begin{abstract}
Summary
Meconium aspiration syndrome (MAS) in newborns is characterized mainly by respiratory failure due to surfactant dysfunction and inflammation. Previous meta-analyses did not prove any effect of exogenous surfactant treatment nor glucocorticoid administration on final outcome of children with MAS despite oxygenation improvement. As we supposed there is the need to intervene in both these fields simultaneously, we evaluated therapeutic effect of combination of exogenous surfactant and selective inhibitor of NF-KB (IKK-NBD peptide). Young New Zealand rabbits were instilled by meconium suspension and treated by surfactant alone or surfactant in combination with IKK-NBD, and oxygen-ventilated for $5 \mathrm{~h}$. $\mathrm{PaO}_{2} / \mathrm{FiO}_{2}$, oxygenation index, oxygen saturation and ventilation efficiency index were evaluated every hour; post mortem, total and differential leukocyte counts were investigated in bronchoalveolar lavage fluid (BALF) and inflammatory, oxidative and apoptotic markers were assessed in lung tissue homogenates. Exogenous surfactant combined with IKK-NBD improved oxygenation, reduced neutrophil count in BALF and levels of IL-1 $\beta$, IL-6, p38 MAPK and caspase 3 in comparison with surfactant-only therapy. It seems that inhibition of inflammation may be strong supporting factor in surfactant treatment of MAS.
\end{abstract}

\section{Key words}

Meconium-induced lung injury • Surfactant treatment • NF-KB • Inflammation • IKK-NBD

\section{Corresponding author}

D. Mokra, Biomedical Center Martin and Department of Physiology, Jessenius Faculty of Medicine in Martin, Comenius
University in Bratislava, Mala Hora 4C, 03601 Martin, Slovakia. E-mail: daniela.mokra@jfmed.uniba.sk

\section{Introduction}

Meconium-induced lung injury in newborns is widely associated with pulmonary inflammation. Meconium-stained amniotic fluid contains cytokines capable of triggering immune response (de Beaufort et al. 2003). Complement and toll-like receptors (TLR) 4 activation with subsequent cytokine production had been found in vitro in the presence of meconium (Salvesen et al. 2009, Salvesen et al. 2010). In vivo, polymorphonuclear activation, free radicals production, cytokine synthesis, phospholipase $\mathrm{A}_{2}$-mediated tissue damage, cell apoptosis and edema formation accompanied main feature of this disease - surfactant dysfunction (Vydiasagar and Zagaryia 2008, Mikolka et al. 2013, Kopincová et al. 2014). What is clinically manifested as serious respiratory failure with the need of exogenous surfactant and ventilatory support, is on the molecular level largely result of many interrelated signaling pathways streaming through activation of nuclear factor $\kappa \mathrm{B}(\mathrm{NF}-\kappa \mathrm{B}$; reviewed in Kopincova and Calkovska 2016). Since all these inflammatory processes are able to impair administered exogenous surfactant and mitigate the treatment efficacy, inhibition of inflammation is one of the targets of current therapeutic interventions. 
Selective NF- $\kappa B$ inhibition by IKK $\gamma$ NEMO Binding Domain (IKK-NBD) inhibitory peptide as an experimental pharmacological tool has been the matter of the last decade. IKK-NBD is cell-permeable low molecular peptide which binds to the regulatory NEMO (NF- $\kappa$ B Essential Modulator) subunit of IKK (I $\mathrm{B}$ kinase) complex, thus preventing $\mathrm{I} \kappa \mathrm{B} \alpha$ (Inhibitor of $\kappa \mathrm{B} \alpha$ ) protein phosphorylation and related $\mathrm{NF}-\kappa \mathrm{B}$ activation (von Bismarck et al. 2012). Recently, its in vivo administration has been examined in connection with various disorders as from rat cerebral ischemia-reperfusion injury model (Desai et al. 2010) through murine Duchenne muscular dystrophy (Reay et al. 2011) to trial in dogs with Diffuse large B-Cell lymphoma (Habineza Ndikuyeze et al. 2014). In respiratory tract, IKK-NBD had favorable effect in the treatment of LPS-induced pulmonary inflammation in mice (von Bismarck et al. 2012) and surfactant "fortifier" in lavage model of ARDS in newborn piglets (Ankermann et al. 2005, von Bismarck et al. 2007, von Bismarck et al. 2009). Considering that meconium aspiration syndrome (MAS) unites main features of both these conditions, surfactant dysfunction and TLR4-mediated inflammation, we were interested if IKK-NBD "upgrade" of surfactant therapy would have an additional benefit in the treatment of experimental MAS.

\section{Methods}

\section{General design of experiments}

Design of experiments was approved by the local Ethics Committee of Jessenius Faculty of Medicine, Comenius University, and National Veterinary Board. It had been published in details previously (Kopincová et al. 2014).

For this series of experiments, we used 21 young New Zealand white rabbits (Velaz s.r.o., Czech Republic) of both genders with body weight (b.w.) of $2.1 \pm 0.1 \mathrm{~kg}$. After all previously described entry procedures (anesthesia and surgery), animals were stabilized for $15 \mathrm{~min}$ on artificial ventilation with frequency of $30 / \mathrm{min}$, fraction of inspired oxygen $\left(\mathrm{FiO}_{2}\right)$ of 0.21 , inspiration time $\mathrm{Ti} 50 \%$, peak inspiratory pressure (PIP) to keep a tidal volume $\left(\mathrm{V}_{\mathrm{T}}\right)$ between $7-9 \mathrm{ml} / \mathrm{kg}$ b.w. and no positive end-expiratory pressure (PEEP). Then, arterial blood samples were obtained for basal values evaluation including blood gases $\left(\mathrm{PaO}_{2}, \mathrm{PaCO}_{2}\right)$ and oxygen saturation $\left(\mathrm{SatO}_{2}\right)$ by RapidLab 348 (Siemens, Germany).

\section{Meconium instillation}

Rabbits were administered meconium suspension $(25 \mathrm{mg} / \mathrm{ml})$ in a dose of $4 \mathrm{ml} / \mathrm{kg}$ b.w. divided into two equal portions while the animals were positioned to the right and left. Following meconium administration, PEEP was adjusted to $0.25-0.3 \mathrm{kPa}$ and $\mathrm{FiO}_{2}$ to 1.0 . Within $30 \mathrm{~min}$ respiratory failure occurred, manifested by decrease in dynamic lung-thorax compliance for more than $30 \%$ and $\mathrm{PaO}_{2}<10 \mathrm{kPa} .30 \mathrm{~min}$ after meconium, all above-mentioned parameters were recorded.

\section{Treatment protocol}

Thirty minutes after meconium administration, the animals were randomly divided into three groups: 1) meconium without treatment (Mec group, $n=7)$; 2) meconium with surfactant-only treatment (Surf group, $\mathrm{n}=7$ ); 3) meconium with combined surfactant and IKK $\gamma$ NEMO Binding Domain Inhibitory peptide (IKK-NBD) treatment (Surf+IKK-NBD group, $n=7$ ).

In surfactant-treated animals, modified porcine surfactant $\left(\right.$ Curosurf $^{\circledR}$, Chiesi Farmaceutici, Italy; $80 \mathrm{mg}$ phospholipids (PL)/ml was administered in two-step procedure as described in details previously (Mikolka et al. 2013, Kopincová et al. 2014). In the first step, lung lavage with Curosurf diluted by saline $\left(37^{\circ} \mathrm{C}\right)$ at $\mathrm{PL}$ concentration of $5 \mathrm{mg} / \mathrm{ml}$ and volume of $10 \mathrm{ml} / \mathrm{kg}$ b.w. had been performed twice and was followed by undiluted Curosurf bolus at a dose of $100 \mathrm{mg} \mathrm{PL} / \mathrm{kg}, 1.25 \mathrm{ml} / \mathrm{kg}$ b.w. using asymmetric high-frequency jet ventilation (f. $300 / \mathrm{min}$, Ti $20 \%$, PIP/PEEP $1.5 / 0.3 \mathrm{kPa}$ ). In Surf+IKK-NBD group, $500 \mu \mathrm{g}$ of IKK-NBD/kg b.w. (AnaSpec, Inc., CA, USA) was dissolved in $0.5 \mathrm{ml}$ of $0.125 \%$ dimethyl sulphoxide (DMSO) and added to surfactant bolus, according to von Bismarck et al. (2009).

Animals were oxygen-ventilated for following $5 \mathrm{~h}$. At $30 \mathrm{~min}, 1,2,3,4$, and $5 \mathrm{~h}$ after the treatment, blood gases and respiratory parameters were recorded. At the end of experiments, animals were sacrificed by an overdose of anesthetics.

\section{Measurement of lung functions parameters}

Tracheal airflow was measured by a heated Fleisch head connected to a pneumotachograph. Airway pressure was registered via a pneumatic catheter placed in the tracheal tube and connected to electromanometer. Mean airway pressure (MAP) was calculated as:

$$
\mathrm{MAP}=(\mathrm{PIP}+\mathrm{PEEP}) / 2 \text {. }
$$

Oxygenation index (OI) was calculated as: 


\author{
$\left.\mathrm{OI}=\left(\mathrm{MAPxFiO}_{2}\right) / \mathrm{PaO}_{2}\right)$; \\ Ventilation efficiency index (VEI) as: \\ VEI $=3800 /\left[(\right.$ PIP-PEEP $] \times$ frequency $\times \mathrm{PaCO}_{2}$.
}

\section{Bronchoalveolar lavage fluid cells evaluation}

Immediately after overdose of anesthetics, lungs and trachea were excised. Left lungs were lavaged by saline $\quad\left(0.9 \% \quad \mathrm{NaCl}, \quad 37^{\circ} \mathrm{C}\right) \quad 3 \times 10 \mathrm{ml} / \mathrm{kg} \quad$ and bronchoalveolar lavage fluid (BALF) was centrifuged at $1500 \mathrm{rpm}$ for $10 \mathrm{~min}$. Total number and differential count of leukocytes in BALF was determined microscopically.

\section{Biochemical analyses in lung tissue homogenates}

For biochemical evaluations, strips of the right lung tissue were homogenized in ice-cold PBS $(0.02 \mathrm{~mol} / \mathrm{l}, \mathrm{pH} 7.2)$ for final concentration $10 \%$ (weight/volume). Homogenates were subjected to two freeze-thaw cycles and centrifuged for $15 \mathrm{~min}$ at $1500 \mathrm{~g}$. Then, supernatants were removed and analyzed.

For cytokine evaluation, ELISA kits for Rabbit IL-1 $\beta$ and IL-6 (USCN Life Science, Wuhan, China) were used according to the manufacturer's instructions. Data were expressed as $\mathrm{pg} / \mathrm{ml}$ of homogenate.

Apoptotic markers were evaluated by $\mathrm{p} 38$ MAPK alpha ELISA Kit (Abcam, Cambridge, UK) and Rabbit Caspase 3 ELISA Kit (Cusabio, Wuhan, China) according to the manufacturer's instructions. Data were expressed as $\mathrm{ng} / \mathrm{ml}$ of homogenate.

For evaluation of oxidative markers, OxiSelect TBARS Assay Kit (Cell Biolabs Inc., San Diego, USA) was used for malondyaldehyde/thiobarbituric reactive substances (TBARS; product of lipid peroxidation). Data were expressed as $\mu \mathrm{mol} / \mathrm{ml}$ of homogenate. Total antioxidant capacity (TAC) was assessed using TAC assay (Abcam, Cambridge, UK) and data were expressed as Trolox equivalent per $\mathrm{ml}$ of homogenate.

\section{Statistical analyses of results}

Statistical analyses were performed by STATISTICA (StatSoft, Inc.; Czech Republic). Two-way analysis of variance (ANOVA) with Duncan post hoc test was used for $\mathrm{PaO}_{2} / \mathrm{FiO}_{2}$, OI, VEI (grouping factors "group" and "time"). Non-parametric analysis (KruskalWallis ANOVA test) was used for comparison of total and differential leukocyte count in BALF, cytokine levels, p38 mitogen-activated protein kinase (MAPK), caspase 3, TBARS and TAC in homogenates of lung tissue. A value of $p<0.05$ was considered to be statistically significant. Numeric values are expressed as mean \pm standard error of mean (SEM).

\section{Results}

The entry parameters (body weight, gender) as well as respiratory parameters did not differ before meconium instillation between groups.

Recovery of the therapeutic bronchoalveolar lavage (BAL) fluid

Therapeutic bronchoalveolar lavage in both surfactant-treated groups (Surf and Surf+IKK-NBD) was performed by $10 \mathrm{ml} / \mathrm{kg}$ of diluted exogenous surfactant. The recovery of therapeutic BAL fluid was similar in both groups $(70.3 \pm 2.1 \%$ for Surf group and $76.0 \pm 3.5 \%$ for Surf+IKK-NBD group, $\mathrm{p}=0.092$, Mann-Whitney U test).

\section{Effect of therapy on the lung functions}

$\mathrm{PaO}_{2} / \mathrm{FiO}_{2}$, VEI, SatO $\mathrm{S}_{2}$ were decreased and OI was increased in $30 \mathrm{~min}$ after meconium administration similarly in all experimental groups $(\mathrm{p}<0.001$ vs. basal values; between-group differences were non-significant).

The administration of surfactant led to transient improvement in $\mathrm{PaO}_{2} / \mathrm{FiO}_{2}$ in the second hour of therapy $(p<0.05$ vs. Mec; Fig. 1A); however, when mean airway pressure was taken into account (parameter OI), the effectivity of surfactant monotherapy was significant from the first $30 \mathrm{~min}$ after administration and this improvement lasted until the end of experiment $(p<0.001$ vs. Mec; Fig. 1B). Oxygen saturation was improved from the first hour of the treatment to the end $(\mathrm{p}<0.01-0.001$ vs. Mec; Fig. 1D). On the other hand, improvement in VEI became evident only in the fifth hour of experiment ( $\mathrm{p}<0.01$ vs. Mec; Fig. 1C).

In comparison with monotherapy, the combination of surfactant treatment and IKK-NBD brought benefit in all measured respiratory parameters. Foremost, the increase in $\mathrm{PaO}_{2} / \mathrm{FiO}_{2}$ and VEI occurred already in the first $30 \mathrm{~min}$ after administration and were significant not only in comparison with untreated group but also with surfactant-treated group ( $\mathrm{p}<0.01$ to 0.001 vs. Mec, $\mathrm{p}<0.05$ vs. Surf; Fig. $1 \mathrm{~A}, \mathrm{C}$ ). This treatment effect persisted for the whole experiment (Fig. 1A, B, C, D) and at the end exceeded the effect of surfactant monotherapy ( $<00.05$ vs. Surf; Fig. $1 \mathrm{~A}, \mathrm{~B})$. 


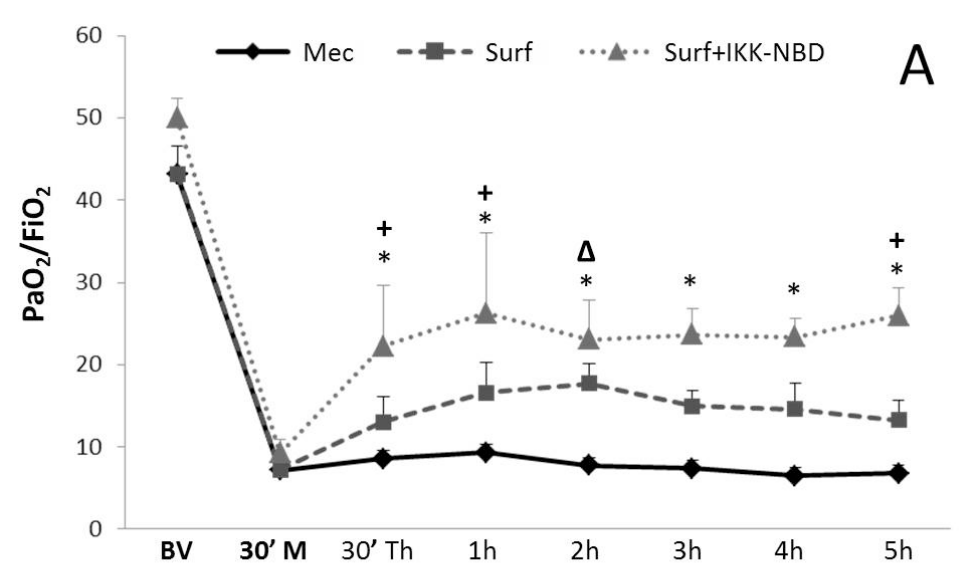

Fig. 1. $\mathrm{PaO}_{2} / \mathrm{FiO}_{2}$ (A), oxygenation index (B), ventilation efficiency index (C) and oxygen saturation (D) before meconium administration (BV), 30 min $\left(30^{\prime}\right)$ after meconium (M) and therapy (Th) administration during $5 \mathrm{~h}$ of experiment. Mec - untreated group; Surf - surfactant-only treated group; Surf+IKK-NBD - surfactant and IKK-NBD-treated group; ${ }^{\Delta} \mathrm{p}<0.05$ to 0.001 for Surf vs. Mec; $* p<0.05$ to 0.001 for Surf+IKK-NBD vs. Mec; $+p<0.05$ to 0.01 for Surf+IKK-NBD vs. Surf.
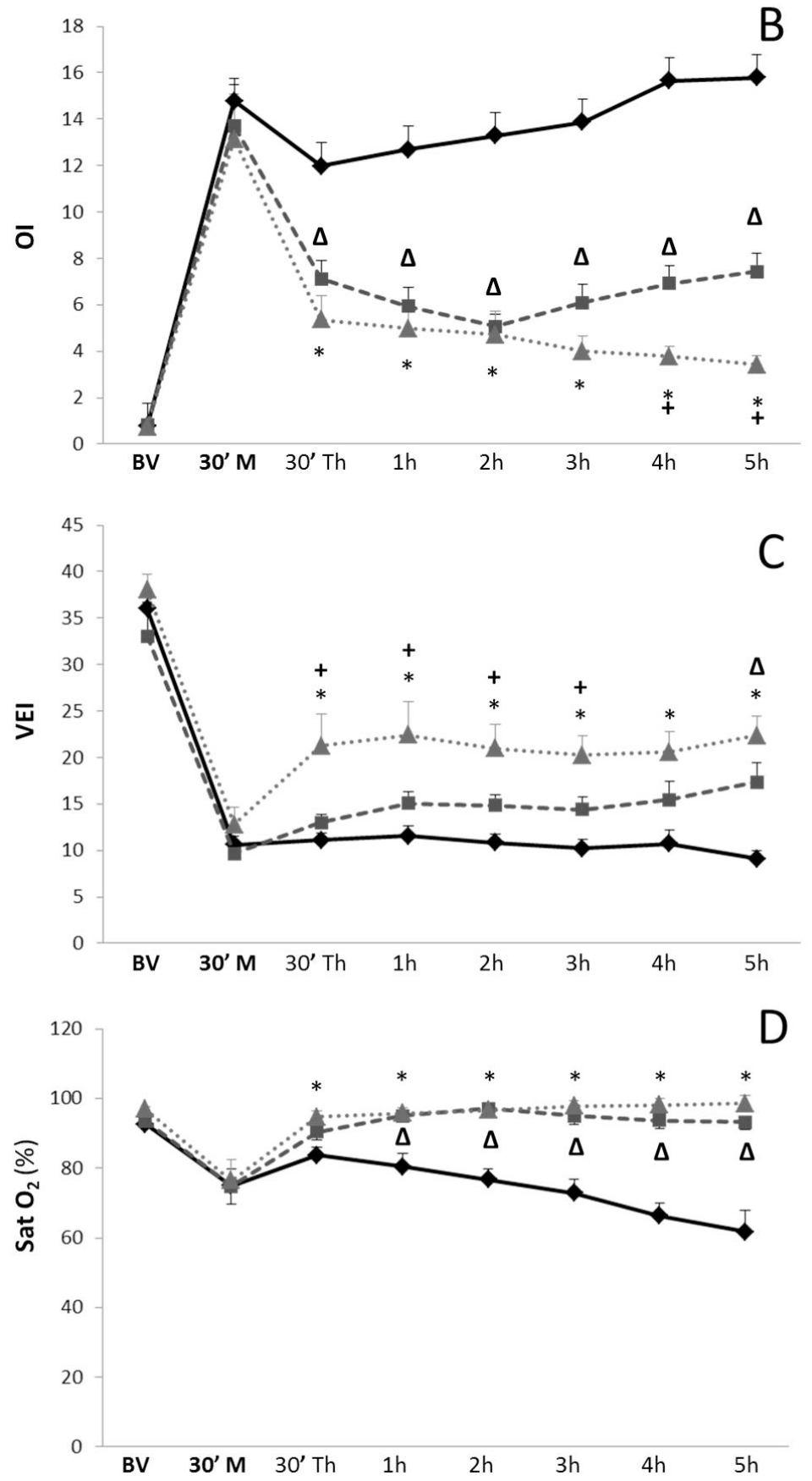
Effect of therapy on leukocyte sequestration into lungs

Post mortem, lavage of left lung was performed, using $3 \times 10 \mathrm{ml} / \mathrm{kg}$ of saline. Recovery of BALF did not differ between groups $(73.2 \pm 5.5 \%$ for Mec; $76.6 \pm 3.2 \%$ for Surf; 78.2 $\pm 5.8 \%$ for Surf+IKK-NBD, all $\mathrm{p}>0.05$ ).

Meconium instillation led to massive influx of leukocytes into the lungs with total count up to $250 \pm 72 \times 10^{7} \mathrm{in} \mathrm{ml} \mathrm{of} \mathrm{BALF.} \mathrm{Both} \mathrm{treatments} \mathrm{decreased}$ the number of leukocytes significantly $(\mathrm{p}<0.01$ for Surf and Surf+IKK-NBD vs. Mec); however, differential leukocyte count was significantly shifted only when combined therapy was used (Table 1). Addition of IKK-NBD to surfactant prevented neutrophil sequestration into the lungs, thus the highest portion of white blood cells stands for monocytes/macrophages $(\mathrm{p}<0.01$ vs. Mec). Relative counts of leukocytes and eosinophils were also decreased in Surf+IKK-NBDtreated group when compared with untreated group ( $<<0.01$ for leukocytes and $\mathrm{p}<0.05$ for eosinophils vs. Mec; Table 1).

Tab. 1. Total and differential leukocyte count in bronchoalveolar lavage fluid (basophil count not shown due to very rare occurrence).

\begin{tabular}{lccccc}
\hline & $\begin{array}{c}\text { Total count } \\
\left(\mathrm{x} 10^{7} / \mathrm{ml}\right)\end{array}$ & Neutrophils (\%) & $\begin{array}{c}\text { Monocytes/ } \\
\text { Macrophages }(\%)\end{array}$ & $\begin{array}{c}\text { Lymphocytes } \\
(\%)\end{array}$ & $\begin{array}{c}\text { Eosinophils } \\
(\%)\end{array}$ \\
\hline Mec & $250.3 \pm 72.0$ & $51.1 \pm 5.2$ & $43.6 \pm 5.4$ & $1.7 \pm 0.3$ & $3.5 \pm 0.7$ \\
Surf & $49.4 \pm 6.7^{\mathrm{a}}$ & $47.8 \pm 7.5$ & $49.2 \pm 7.5$ & $1.2 \pm 0.2$ & $1.8 \pm 0.4$ \\
Surf + IKK-NBD & $51.3 \pm 8.3^{\mathrm{a}}$ & $22.8 \pm 7.2^{\mathrm{a}}$ & $75.4 \pm 7.4^{\mathrm{a}}$ & $0.4 \pm 0.1^{\mathrm{ac}}$ & $1.4 \pm 0.3^{\mathrm{b}}$ \\
\hline
\end{tabular}

Mec - untreated group; Surf - Surfactant-only treated group; Surf+IKK-NBD - Surfactant and IKK-NBD treated group; ${ }^{a} p<0.01$ vs. Mec; ${ }^{b} p<0.05$ vs. Mec; ${ }^{c} p<0.05$ vs. Surf.

\section{Effect of therapy on lung tissue inflammation}

\section{Cytokine levels}

Surfactant administration only led to nonsignificant (IL-1 $\beta$ ) or completely no change (IL-6) in cytokine levels (Table 2). Combination of surfactant and
IKK-NBD prevented meconium-induced interleukin (IL)- $1 \beta$ and IL-6 formation in lung tissue ( $p<0.01$ for IL- $1 \beta$ and $p<0.05$ for IL-6 vs. Mec). Moreover, the decrease in IL-6 was pronounced in comparison with surfactant-only treated animals ( $<0.05$; Table 2 ).

Tab. 2. Levels of interleukin (IL)-1 $\beta$, IL-6, p38 Mitogen-activated protein kinase (p38 MAPK), Caspase 3, Thiobarbituric acid reactive substances (TBARS) and Total antioxidant capacity (TAC) in lung tissue homogenates.

\begin{tabular}{lcccccc}
\hline & $\begin{array}{c}\text { IL-1; } \\
(\mathrm{pg} / \mathrm{ml})\end{array}$ & $\begin{array}{c}\text { IL-6 } \\
(\mathrm{pg} / \mathrm{ml})\end{array}$ & $\begin{array}{c}\text { p38 MAPK } \\
(\mathrm{ng} / \mathrm{ml})\end{array}$ & $\begin{array}{c}\text { Caspase 3 } \\
(\mathrm{ng} / \mathrm{ml})\end{array}$ & $\begin{array}{c}\text { TBARS } \\
(\mu \mathrm{mol} / \mathrm{ml})\end{array}$ & $\begin{array}{c}\text { TAC } \\
(\mathrm{TE} / \mathrm{ml})\end{array}$ \\
\hline Mec & $332.2 \pm 19.7$ & $4.7 \pm 0.5$ & $78.1 \pm 6.6$ & $5.2 \pm 0.6$ & $30.3 \pm 3.4$ & $14.0 \pm 0.7$ \\
Surf & $272.8 \pm 32.5$ & $4.5 \pm 0.8$ & $81.6 \pm 3.9$ & $5.7 \pm 0.4$ & $21.9 \pm 1.5$ & $16.7 \pm 0.7$ \\
Surf $+I K K-N B D$ & $166.8 \pm 8.7^{\mathrm{a}}$ & $2.2 \pm 0.4^{\mathrm{bd}}$ & $57.1 \pm 3.0^{\mathrm{ac}}$ & $3.5 \pm 0.4^{\mathrm{bd}}$ & $23.4 \pm 8.5$ & $17.1 \pm 0.9^{\mathrm{x}}$ \\
\hline
\end{tabular}

Mec - untreated group; Surf - Surfactant-only treated group; Surf+IKK-NBD - Surfactant and IKK-NBD treated group; TE - Trolox equivalent; ${ }^{a} p<0.01$ vs. Mec; ${ }^{b} p<0.05$ vs. Mec; ${ }^{c} p<0.01$ vs. Surf; ${ }^{d} p<0.05$ vs. Surf; ${ }^{x} p=0.07$ vs. Mec.

\section{Cytokine levels}

Surfactant administration only led to nonsignificant (IL-1 $\beta$ ) or completely no change (IL-6) in cytokine levels (Table 2). Combination of surfactant and IKK-NBD prevented meconium-induced interleukin (IL)$1 \beta$ and IL-6 formation in lung tissue ( $<<0.01$ for IL- $1 \beta$ and $p<0.05$ for IL- 6 vs. Mec). Moreover, the decrease in IL-6 was pronounced in comparison with surfactant-only treated animals ( $<<0.05$; Table 2$)$.

\section{Apoptotic markers}

Apoptotic signalization was diminished after IKK-NBD administration. Levels of both evaluated markers p38 MAPK and caspase 3 were decreased in group with combined therapy when compared to untreated group or surfactant-treated group $(\mathrm{p}<0.01$ for 
p38 MAPK and $\mathrm{p}<0.05$ for caspase 3 vs. both Mec and Surf; Table 2).

\section{Oxidative markers}

Markers of oxidative stress in lung tissue presented by TBARS and TAC evaluation were not significantly affected by any of the treatment. Decrease in TBARS formation after therapeutic intervention was not significant, while in TAC there was just tendency to amelioration after combined therapy $(p=0.07$ vs. Mec; Table 2).

\section{Discussion}

Meconium present in newborn's lungs causes a number of alterations often resulting in severe respiratory failure with need of ventilatory support and exogenous surfactant treatment, as endogenous surfactant is degraded and dysfunctional (Mokra et al. 2013).

In our experiments, meconium led to marked deterioration in all respiratory parameters in very short time after instillation. Ventilation/perfusion mismatch in Mec group was reflected by reduced oxygen saturation up to $61 \%$ at $\mathrm{OI}>15$. Upon removal, lungs of untreated animals were atelectatic at sight and BALF was rich in cells with high portion of neutrophils.

Meconium-induced surfactant dysfunction is multilevel process, starting with direct effect of meconium on surfactant components and ending with harmful inflammatory and oxidative cascades (Kopincova and Calkovska 2016). Despite confirmed deleterious effect on endogenous surfactant, effectivity of exogenous surfactant given as in newborns with MAS is still discussed. Systematic reviews and meta-analyses did not prove its benefit on newborns' final outcome, regardless of improvement in pulmonary oxygenation (Lee and Kim 2013, El Shahed et al. 2014). On the other side, there is growing evidence of surfactant lavage benefit in both experimental and clinical MAS (Lista et al. 2006, Dargaville 2012a, Lin et al. 2014) with some authors finding the combination of surfactant lavage and bolus the most effective treatment (Henn et al. 2015). This resulted in the fact, that some current national guidelines recommend therapeutic use of exogenous surfactant in severe MAS (Castillo Salinas et al. 2015, Chettri et al. 2016).

In our study, combination of lavage with diluted surfactant followed by surfactant bolus turned out to be effective on some ventilatory parameters. Improvement in
OI and oxygen saturation was seen in the first hour after the treatment; improvement in VEI was restricted to the last hour of the experiment probably due to persisting airway obstruction.

Lavage with surfactant is useful tool for washing out meconium from obstructed airways (Ohama and Ogava 1999). Together with meconium, cytokines, chemokines and phospholipases are removed, resulting in mitigation of chemotactic stimuli and inflammation. In accordance with this, we found marked decrease in leukocyte sequestration into lungs after surfactant treatment, though the portion of neutrophils was still higher compared to Surf+IKK-NBD group. However, cytokines were not reduced in Surf group what is in accordance with our other study (Mikolka et al. 2016c). Recently we have shown that surfactant treatment in experimental MAS may decrease cytokine expression on mRNA levels, nevertheless, it was not capable of preventing also translational process (discussed in Mikolka et al. 2016a). There was also only nonsignificant decrease in lipid peroxidation after surfactant; non-significance in this group might be, however, accounted to wide variance of data. When we compared only Mec and Surf group using non-parametric Mann-Whitney $U$ test, significance was marked, in accordance with our previous results, where surfactant treatment prevented oxidative damage in lung tissue and systemic circulation (Kopincová et al. 2014, Mikolka et al. 2016b). And finally, no change in apoptotic markers suggests that small amount of residual meconium is able to initiate inflammatory cascades which in turn activate each other (Kopincova and Calkovska 2016).

Considering inferior effect of anti-inflammatory monotherapy (without surfactant) in MAS (Mikolka et al. 2013) and after comparison with other studies using IKK-NBD combined with surfactant (Ankermann et al. 2005, von Bismarck et al. 2009) we did not include IKK-NBD-treated animals without surfactant. Surfactant administration is now considered to be an integral component of the management of MAS, especially for those newborns who are intubated (Canadian Paediatric Society 2005, Stenson and Smith 2012) while corticoid monotherapy should not be considered standard practice in the meantime (Dargaville 2012b, Stenson and Smith 2012). Thus, solely IKK-NBD therapy, presumably, would not be in clinical use.

In MAS, surfactant dysfunction and lung inflammation are two main conditions to fight with, when obstructive effect of meconium is diminished by 
suctioning. Surfactant replacement improves oxygenation, but may be additionally impaired by running inflammation. Damping inflammation without surfactant substitution seems to be weak tool to completely overcome deleterious effects of meconium on surface tension in airways. These might be the reasons, why the final outcome of newborns in systematic reviews did not change nor after corticosteroids neither after surfactant despite early improvement in oxygenation (Ward and Sinn 2003, El Shahed et al. 2014, Garg et al. 2016).

To the contrary, "upgrade" of surfactant therapy with anti-inflammatory agent may bring an additional benefit (Mikolka et al. 2013, Kopincová et al. 2014, Lin et al. 2016). IKK-NBD, selective inhibitor of NF- $\mathrm{BB}$, combined with surfactant seems to be promising in the treatment of respiratory distress syndrome (Ankermann et al. 2005, von Bismarck 2007, von Bismarck 2009). In this study, quick onset and persisting effect of the therapy was seen in all measured respiratory parameters. Lower leukocyte migration to lungs, reduced portion of sequestrated neutrophils, decrease in inflammatory cytokine levels and apoptotic pathway markers were seen after successful NF- $\kappa$ B inhibition.

Combined therapy led to rapid improvement in oxygenation in the first $30 \mathrm{~min}$ after administration and reached values (especially in VEI and $\mathrm{PaO}_{2} / \mathrm{FiO}_{2}$ ) which were higher than in surfactant-only treated animals, suggesting that this effect cannot be ascribed just to meconium removal by lavage. To explain this observation is challenging issue. Such quick onset of therapeutic effect in MAS has been previously noticed by our group after treatment with surfactant + budesonide (Mikolka et al. 2013) and surfactant $+\mathrm{N}$-acetylcysteine (Kopincová et al. 2014). In the case of glucocorticoid administration, prompt reply occurs probably due to nongenomic effects of corticoids which include interactions of glucocorticoids with cellular membranes, specific interaction with membrane-bound glucocorticoid receptors, and non-genomic effects mediated through binding to the cytosolic glucocorticoid receptors (Alangari et al. 2010) - none of these can be reached using IKK-NBD. In the latter case, changes in redox status might affect redox-sensitive p38 MAPK pathway leading to cyclooxygenase-2 (COX-2) induction and subsequent thromboxane production (Zafarullah et al. 2003, Bernatova 2014). Inhibition of COX-2 (and thromboxane) might prevent bronchoconstriction, lower airway resistance and improve lung function parameters
(Uhlig et al. 1996, Kopincová et al. 2014).

Recently, it has been shown that COX-2 induction in airway smooth muscle cells and COX-2-derived lung inflammation may be triggered also via $\mathrm{PI} 3 \mathrm{~K} / \mathrm{Akt} / \mathrm{NF}-\kappa \mathrm{B}$ pathway after activation of EGFR/PDGFR (Yang et al. 2009). These receptors can be rapidly activated by adenosine released from injured epithelial cells, leading to immediate COX-2-mediated airway constriction (Zhou et al. 2013). Taken together, in meconium-polluted airways where multiple agents including phospholipase A2 can directly damage epithelial cells, inhibition of NF- $\mathrm{BB}$-dependent COX-2 induction may prevent prostanoid bronchoconstriction and improve oxygenation. But of course, many other mechanisms can stand behind this fast effect of combined therapy and more studies are needed to clarify this observation.

Inhibition of inflammatory signalization led to reduction in cytokine production. Meconium is known to activate TLR4/MD-2/CD14 complex - that means, the starting point of LPS-induced inflammation and the first signal point for both IL-1 $\beta$ and IL-6 transcription ( $\mathrm{Lu}$ et al. 2008). Downregulation of these pathways damped not only cytokine levels but also chemokine production, manifested by reduction in the number of migrating cells and the portion of neutrophils in the lungs. Hand in hand, decrease in p38 MAPK and caspase 3 levels were found in lung tissue homogenates after combined therapy. p38 MAPK expression is not NF- $\mathrm{BB}$-dependent, but is increased after cytokine stimulation of the cell (Pelaia et al. 2005). Its induction results in apoptosis mediated by caspase 3 (Damarla et al. 2014). Reduction in these substances suggests less apoptotic signalization in injured lungs.

Finally, there is some unclarity about low effect of combined therapy on oxidative parameters in the lung tissue. No change in TBARS formation and only tendency to improvement in antioxidant capacity in the tissue were seen after Surf+IKK-NBD administration, though it is known that inductive nitric oxide synthase (iNOS) induction is NF-kB-dependent (Kopincová et al. 2011) and expression of some subunits of nicotinamide adenine dinucleotide phosphate (NADPH)-oxidase requires NF- $\kappa \mathrm{B}$ activity (Anrather et al. 2006, Manea et al. 2007). Oxidative damage had not been prevented even after restriction of neutrophil activity in the lungs, so perhaps some other activated cells, e.g. epithelial or endothelial, were engaged in this process. As free radicals have strong potential not only to harm the tissue, but are 
also essential in inflammatory signaling, down-regulation of their production in MAS is desirable.

Taken together, combination of exogenous surfactant and IKK-NBD was superior to surfactant monotherapy as regards lung function and some inflammatory markers. Anti-inflammatory "upgrade" of surfactant therapy may thus be taken into account in the management of MAS in the future.

\section{Conflict of Interest}

There is no conflict of interest.

\section{Acknowledgements}

The authors thank Ing. M. Petrášková, Ing. M. Hutko, D. Kulíšková and Z. Remišová for technical assistance. The study was supported by Project "BioMed Martin" No. 26220220187; Project APVV-0435-11, APVV-150075 and VEGA 1/0305/14.

\section{References}

ALANGARI AA: Genomic and non-genomic actions of glucocorticoids in asthma. Ann Thorac Med 5: 133-139, 2010.

ANKERMANN T, REISNER A, WIEMANN T, KRAMS M, KÖHLER H, KRAUSE MF: Topical inhibition of nuclear factor-kappaB enhances reduction in lung edema by surfactant in a piglet model of airway lavage. Crit Care Med 33: 1384-1391, 2005.

ANRATHER J, RACCHUMI G, IADECOLA C: NF-kappaB regulates phagocytic NADPH oxidase by inducing the expression of gp91phox. J Biol Chem 281: 5657-5667, 2006.

BARNES PJ: Pharmacology of airway smooth muscle. Am J Respir Crit Care Med 158: S123-S132, 1998.

BERNATOVÁ I: Endothelial dysfunction in experimental models of arterial hypertension: cause or consequence?. Biomed Res Int 2014: 598271, 2014.

CANADIAN PAEDIATRIC SOCIETY: Recommendations for neonatal surfactant therapy. Paediatr Child Health 10: 109-116, 2005.

CASTILLO SALINAS F, ELORZA FERNÁNDEZ D, GUTIÉRREZ LASO A, MORENO HERNANDO J, BUSTOS LOZANO G, GRESA MUNOZ M, LÓPEZ DE HEREDIA GOYA J, AGUAR CARRASCOSA M, MIRACLE ECHEGOYEN X, FERNÁNDEZ LORENZO JR, ET AL.: Recommendations for respiratory support in the newborn (iii). Surfactant and nitric oxide. (In Spanish) An Pediatr (Barc) 83: 354.e1-354.e6, 2015.

CHETTRI S, BHAT BV, ADHISIVAM B: Current concepts in the management of Meconium Aspiration Syndrome. Indian J Pediatr 83: 1125-1130, 2016.

DAMARLA M, PARNIANI AR, JOHNSTON L, MAREDIA H, SEREBRENI L, HAMDAN O, SIDHAYE VK, SHIMODA LA, MYERS AC, CROW MT, ET AL.: Mitogen-activated protein kinase-activated protein kinase 2 mediates apoptosis during lung vascular permeability by regulating movement of cleaved caspase 3 . Am J Respir Cell Mol Biol 50: 932-941, 2014.

DARGAVILLE PA: Innovation in surfactant therapy I: surfactant lavage and surfactant administration by fluid bolus using minimally invasive techniques. Neonatology 101: 326-336, 2012a.

DARGAVILLE PA: Respiratory support in meconium aspiration syndrome: a practical guide. Int J Pediatr 2012: 965159, 2012b.

DE BEAUFORT AJ, BAKKER AC, VAN TOL MJ, POORTHUIS BJ, SCHRAMA AJ, BERGER HM: Meconium is a source of pro-inflammatory substances and can induce cytokine production in cultured A549 epithelial cells. Pediatr Res 54: 491-495, 2003.

DESAI A, SINGH N, RAGHUBIR R: Neuroprotective potential of the NF- $\kappa$ B inhibitor peptide IKK-NBD in cerebral ischemia-reperfusion injury. Neurochem Int 57: 876-883, 2010.

EL SHAHED AI, DARGAVILLE PA, OHLSSON A, SOLL R: Surfactant for meconium aspiration syndrome in term and late preterm infants. Cochrane Database Syst Rev 12: CD002054, 2014.

GARG N, CHOUDHARY M, SHARMA D, DABI D, CHOUDHARY JS, CHOUDHARY SK: The role of early inhaled budesonide therapy in meconium aspiration in term newborns: a randomized control study. $J$ Matern Fetal Neonatal Med 29: 36-40, 2016.

HABINEZA NDIKUYEZE G, GAURNIER-HAUSSER A, PATEL R, BALDWIN AS, MAY MJ, FLOOD P, KRICK E, PROPERT KJ, MASON NJ: A phase I clinical trial of systemically delivered NEMO binding domain peptide in dogs with spontaneous activated B-cell like diffuse large B-cell lymphoma. PLoS One 9: e95404, 2014. 
HENN R, FIORI RM, FIORI HH, PEREIRA MR, COLVERO MO, RAMOS GARCIA PC, PADOIM P, STIVANIN JB: Surfactant with and without bronchoalveolar lavage in an experimental model of meconium aspiration syndrome. J Perinat Med 44: 685-689, 2016.

KOPINCOVA J, CALKOVSKA A: Meconium-induced inflammation and surfactant inactivation: specifics of molecular mechanisms. Pediatr Res 79: 514-521, 2016.

KOPINCOVÁ J, MOKRÁ D, MIKOLKA P, KOLOMAZNÍK M, ČALKOVSKÁ A: N-acetylcysteine advancement of surfactant therapy in experimental meconium aspiration syndrome: possible mechanisms. Physiol Res $\mathbf{6 3}$ (Suppl 4): S629-S642, 2014.

KOPINCOVÁ J, PÚZSEROVÁ A, BERNÁTOVÁ I: Biochemical aspects of nitric oxide synthase feedback regulation by nitric oxide. Interdiscip Toxicol 4: 63-68, 2011.

LEE SL, KIM CS: Surfactant therapy in severe meconium aspiration syndrome. Neonat Med 20: 318-322, 2013.

LIN CH, JENG MJ, KUO BI, KOU YR: Effects of surfactant lavage combined with intratracheal budesonide instillation on meconium-injured piglet lungs. Pediatr Crit Care Med 17: e287-e295, 2016.

LIN XZ, LAI JD, LAN ZY, LIN YY: Clinical effect of endotracheal lavage with porcine pulmonary surfactant in term neonates with severe meconium aspiration syndrome. (In Chinese) Zhongguo Dang Dai Er Ke Za Zhi 16: 709-713, 2014.

LISTA G, BIANCHI S, CASTOLDI F, FONTANA P, CAVIGIOLI F: Bronchoalveolar lavage with diluted porcine surfactant in mechanically ventilated term infants with meconium aspiration syndrome. Clin Drug Investig 26: 13-19, 2006.

LU YC, YEH WC, OHASHI PS: LPS/TLR4 signal transduction pathway. Cytokine 42: 145-151, 2008.

MANEA A, MANEA SA, GAFENCU AV, RAICU M: Regulation of NADPH oxidase subunit p22(phox) by NF-kB in human aortic smooth muscle cells. Arch Physiol Biochem 113: 163-172, 2007.

MIKOLKA P, KOPINCOVA J, MIKUSIAKOVA LT, KOSUTOVA P, CALKOVSKA A, MOKRA D: Antiinflammatory effect of N-Acetylcysteine combined with exogenous surfactant in meconium-induced lung injury. Adv Exp Med Biol 934: 63-75, 2016a.

MIKOLKA P, KOPINCOVA J, TOMCIKOVA MIKUSIAKOVA L, KOSUTOVA P, ANTOSOVA M, CALKOVSKA A, MOKRA D: Effects of surfactant/budesonide therapy on oxidative modifications in the lung in experimental meconium-induced lung injury. J Physiol Pharmacol 67: 57-65, $2016 \mathrm{~b}$.

MIKOLKA P, MOKRÁ D, KOPINCOVÁ J, TOMČÍKOVÁ-MIKUŠIAKOVÁ L, ČALKOVSKÁ A: Budesonide added to modified porcine surfactant Curosurf may additionally improve the lung functions in meconium aspiration syndrome. Physiol Res 62 (Suppl 1): S191-S200, 2013.

MIKOLKA P, KOPINCOVA J, KOSUTOVA P, CIERNY D, CALKOVSKA A, MOKRA D: Lung inflammatory and oxidative alterations after exogenous surfactant therapy fortified with budesonide in rabbit model of meconium aspiration syndrome. Physiol Res 65 (Suppl 5): S653-S662, 2016c.

MOKRA D, DRGOVA A, KOPINCOVA J, PULLMANN R, CALKOVSKA A: Anti-inflammatory treatment in dysfunction of pulmonary surfactant in meconium-induced acute lung injury. Adv Exp Med Biol 756: 189-196, 2013.

OHAMA Y, OGAWA Y: Treatment of meconium aspiration syndrome with surfactant lavage in an experimental rabbit model. Pediatr Pulmonol 28: 18-23, 1999.

PELAiA G, CUDA G, VATRELlA A, GALLELli L, CARAGLIA M, MARRA M, ABBRUZZESE A, CAPUTI M, MASELLI R, COSTANZO FS, MARSICO SA: Mitogen-activated protein kinases and asthma. J Cell Physiol 202: 642-653, 2005.

REAY DP, YANG M, WATCHKO JF, DAOOD M, O'DAY TL, REHMAN KK, GUTTRIDGE DC, ROBBINS PD, CLEMENS PR: Systemic delivery of NEMO binding domain/IKK $\gamma$ inhibitory peptide to young mdx mice improves dystrophic skeletal muscle histopathology. Neurobiol Dis 43: 598-608, 2011.

SALVESEN B, NIELSEN EW, HARBOE M, SAUGSTAD OD, MOLLNES TE: Mechanisms of complement activation and effects of $\mathrm{C} 1$-inhibitor on the meconium-induced inflammatory reaction in human cord blood. Mol Immunol 46: 688-694, 2009. 
SALVESEN B, STENVIK J, ROSSETTI C, SAUGSTAD OD, ESPEVIK T, MOLLNES TE: Meconium-induced release of cytokines is mediated by the TRL4/MD-2 complex in a CD14-dependent manner. Mol Immunol 47: 1226-1234, 2010.

UHLIG S, NÜSING R, VON BETHMANN A, FEATHERSTONE RL, KLEIN T, BRASCH F, MÜLLER KM, ULLRICH V, WENDEL A: Cyclooxygenase-2-dependent bronchoconstriction in perfused rat lungs exposed to endotoxin. Mol Med 2: 373-383, 1996.

VIDYASAGAR D, ZAGARIYA A: Studies of meconium-induced lung injury: inflammatory cytokine expression and apoptosis. J Perinatol 28 (Suppl 3): S102-S107, 2008.

VON BISMARCK P, KLEMM K, GARCÍA WISTÄDT CF, WINOTO-MORBACH S, SCHÜTZE S, KRAUSE MF: Selective NF-kappaB inhibition, but not dexamethasone, decreases acute lung injury in a newborn piglet airway inflammation model. Pulm Pharmacol Ther 22: 297-304, 2009.

VON BISMARCK P, KLEMM K, WISTÄDT CF, WINOTO-MORBACH S, UHLIG U, SCHÜTZE S, UHLIG S, LACHMANN B, KRAUSE MF: Surfactant "fortification" by topical inhibition of nuclear factor-kappaB activity in a newborn piglet lavage model. Crit Care Med 35: 2309-2318, 2007.

VON BISMARCK P, WINOTO-MORBACH S, HERZBERG M, UHLIG U, SCHÜTZE S, LUCIUS R, KRAUSE MF: IKK NBD peptide inhibits LPS induced pulmonary inflammation and alters sphingolipid metabolism in a murine model. Pulm Pharmacol Ther 25: 228-235, 2012.

WARD M, SINN J: Steroid therapy for meconium aspiration syndrome in newborn infants. Cochrane Database Syst Rev 4: CD003485, 2003.

YANG CM, LEE IT, LIN CC, YANG YL, LUO SF, KOU YR, HSIAO LD: Cigarette smoke extract induces COX-2 expression via a PKCalpha/c-Src/EGFR, PDGFR/PI3K/Akt/NF-kappaB pathway and p300 in tracheal smooth muscle cells. Am J Physiol Lung Cell Mol Physiol 297: L892-L902, 2009.

ZAFARULLAH M, LI WQ, SYLVESTER J, AHMAD M: Molecular mechanisms of N-acetylcysteine actions. Cell Mol Life Sci 60: 6-20, 2003.

ZHOU J, ALVAREZ-ELIZONDO MB, BOTVINICK E, GEORGE SC: Adenosine A(1) and prostaglandin E receptor 3 receptors mediate global airway contraction after local epithelial injury. Am J Respir Cell Mol Biol 48: 299-305, 2013. 